\title{
Effectiveness of Video Assisted Teaching on Knowledge Regarding Breast Self Examination among Women in Selected Rural Area at Villupuram District
}

\author{
M. Porselvi ${ }^{1}$, M. Muthamizh ${ }^{2}$, E. Pathima ${ }^{3}$, M. Nandhini ${ }^{4}$, M. Poyyamozhi ${ }^{5}$, \\ M. Nivetha $^{6}$, P. Pragadeswari ${ }^{7}$, S. Prasannadevi $^{8}$ \\ ${ }^{1}$ Professor cum Principal, E. S. College of Nursing, Villupuram, Tamilnadu \\ ${ }^{2-8}$ B.Sc (N) E. S. College of Nursing, Villupuram, Tamilnadu
}

Corresponding Author: M. Porselvi

\begin{abstract}
Aim: The study aims to create awareness among women regarding incidence, risk factors, clinical symptoms, prevention and management of Breast Cancer through Breast self examination.

Objectives: i) To assess the pre and post test level of knowledge regarding Breast self examination among women. ii) to assess the effectiveness of video assisted teaching on knowledge regarding Breast self examination among women. iii) to find the association between post test level of knowledge regarding breast self examination among women with their demographic variables.
\end{abstract}

Methods Material: A quantitative research approach - experimental - pre- experimental-one group- pre -test post-test research design was adopted. 30 samples were selected for the study by using non probable-purposive sampling technique.

Results: the study findings shows that in pre test level of knowledge among 30 samples $25(83.4 \%)$ had inadequate knowledge and $5(16.6 \%)$ had moderate adequate knowledge. In post test level of knowledge among 30 sample $8(26.6 \%)$ had moderate adequate knowledge and $22(73 \%)$ had adequate knowledge.

Conclusion: the study concluded that, video assisted teaching programme regarding breast self examination was effective on improving the knowledge level among women in selected settings of rural area.

Keywords: Breast Cancer, Breast self examination, Video assisted teaching.

\section{INTRODUCTION}

Cancer is one of the most life threaten human health in the world. Cancer is a group of disease involving abnormal cell growth with the potential to invade or spread to other parts of the body.

Cancer is classified by the type of the cell that the tumor cells resemble and is therefore presumed to be the origin of the tumor. The type of carcinoma, sarcoma, lymphoma and leukaemia and blastoma and seminoma.

Possible signs and symptoms include a lump, abnormal bleeding, prolonged cough, unexplained weight loss, and a change in bowel movements while these symptoms may indicate cancer. Many cancer can be prevented by stop smoking, maintained healthy weight, not drinking too much alcohol, eating plenty of vegetables, fruits, whole grains, vaccination against certain infectious disease, not eating too much sunlight exposure foods.

Breast cancer is a major health concern as it is the second leading cancer death in women, exceeded only by lung cancer. Most breast cancer benign either in the breast tissue made up of glands for milk production called lobules or in the ducts that connect the lobules to the nipples.

Signs of the breast cancer may include a lump in the breast, a change in the breast, shape dimpling of the skin, fluid 
coming from the nipples a newly inverted nipples a red or scaly patch of skin.

Prevention is better than cure measuring should be taken to prevent cancerous lesion by detecting it at earliest stages. Breast screening in general population has shown to reduce mortality and helps to detect it at earliest stage, breast self examination is a technique that all women can use to assess their own breast women familiar with their own normal breast characteristics can easily notice the development of abnormalities early. Each women and girls should be aware of her own risk factors with regular breast self examination, malignancy may be discovered. Early and effectively treated, regular monthly breast self examination is an essential health maintenance activity. (Beverly. B et al (2014)

Breast self examination is a screening method used in attempt to detect early breast cancer. The method involves the women herself looking at and feeling each breast for lumps distortion or swelling.

\section{OBJECTIVES OF THE STUDY:}

- To assess the pre and post test level of knowledge regarding Breast self examination among women.

- To assess the effectiveness of video assisted teaching on knowledge regarding Breast self examination among women.

- Find the association between post test level of knowledge regarding Breast self examination among women with their selected demographic variables.

\section{NULL HYPOTHESIS}

NH1- There is no significant difference between the pre and post test level of knowledge regarding Breast self examination among women.

NH2- There is no significant association between post test level of knowledge regarding Breast self examination among women with their selected sociodemographic variables.

\section{METHODS}

A quantitative research approach Experimental- Pre-experimental one group pre test post test research design was adopted. 30 samples were selected for the study by using non probable purposive sampling technique.

\section{RESULT AND DISCUSSION}

Assessment of pre and post test level of knowledge regarding Breast self examination among women in selected settings of rural area.

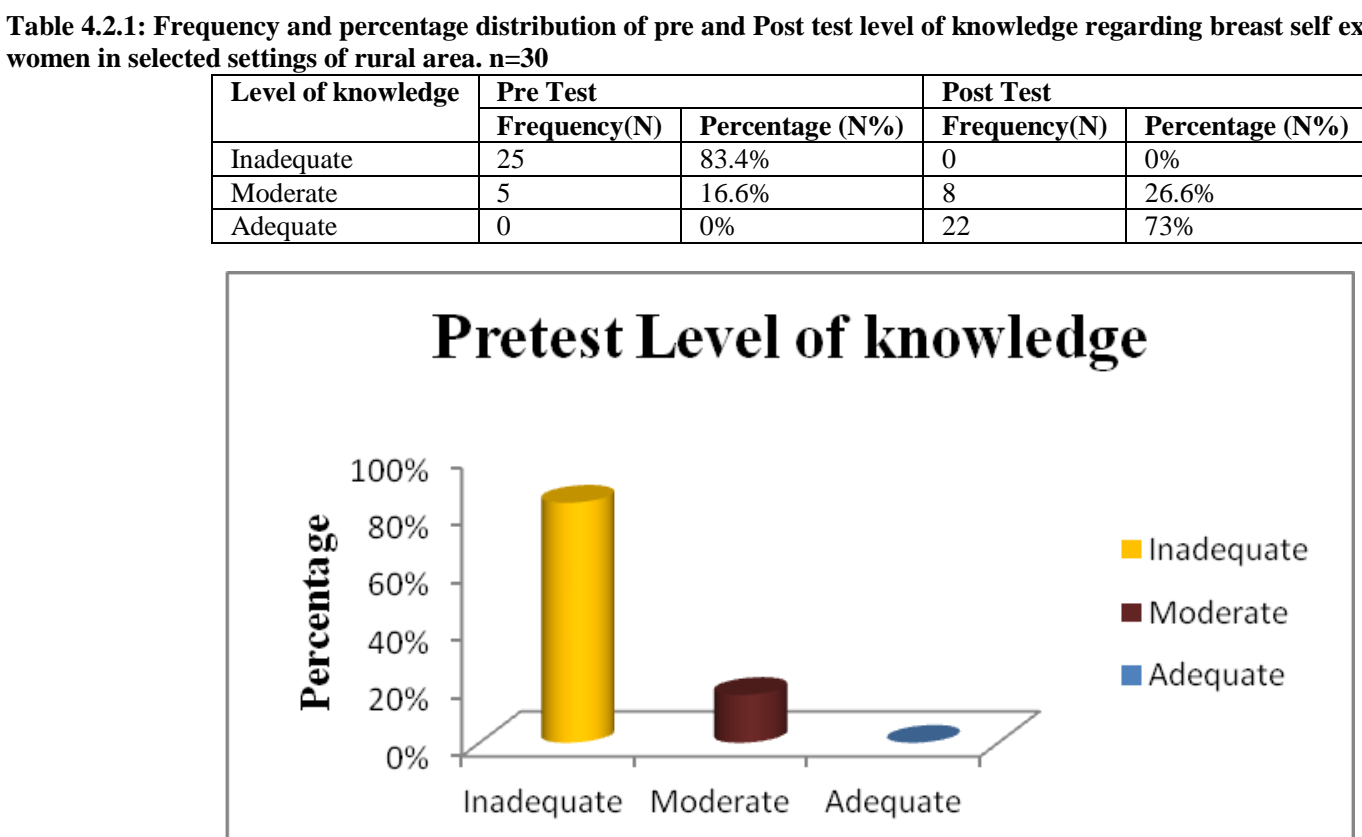

Figure 4.2.1: Shows percentage distribution of pre test level of knowledge regarding breast self examination among women 


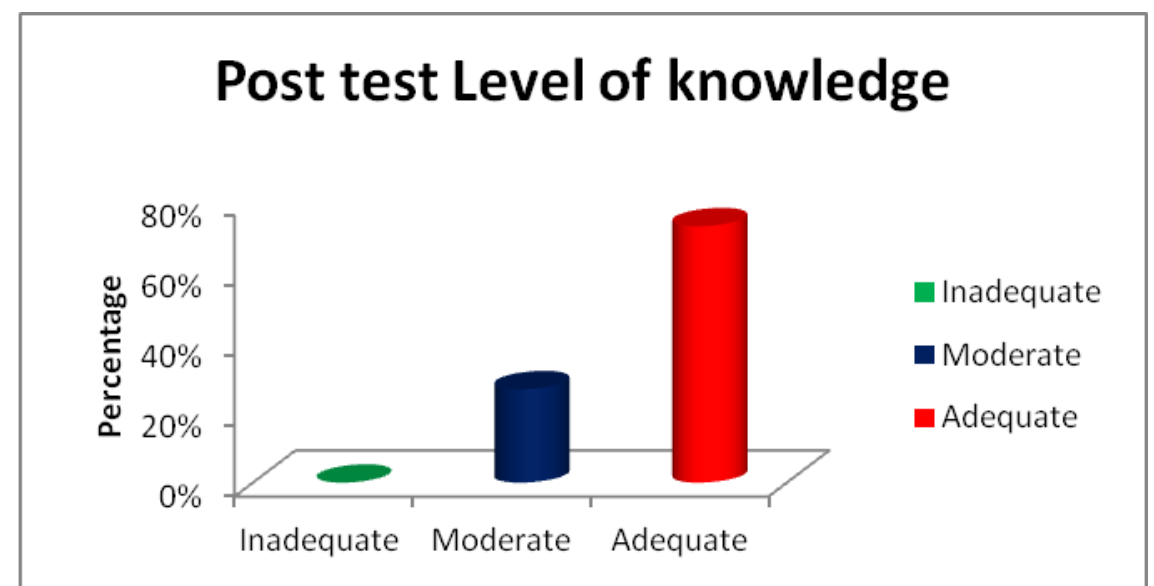

Figure 4.2.2: shows percentage distribution of post test level of knowledge regarding breast self examination among women

Table 4.2.1: Shows that in pre test level of knowledge among 30 samples $25(83.4 \%)$ had inadequate knowledge, $5(16.6 \%)$ had moderate adequate knowledge, $0(0 \%)$ had adequate knowledge. In post test level of knowledge among 30 samples $0(0 \%)$ had inadequate knowledge, $8(26.6 \%)$ had moderate adequate knowledge, 22(73\%) had adequate knowledge.

\section{SECTION-III}

Effectiveness of video assisted teaching program on knowledge regarding Breast self examination among women in selected settings of rural area.

Table.4.3.1: Comparison of per test and post test scores of knowledge regarding breast self examination.

$$
\mathbf{n}=\mathbf{3 0}
$$

\begin{tabular}{|l|l|l|l|l|}
\hline Group & Test & Mean & SD & $\begin{array}{l}\text { Paired 't' } \\
\text { value }\end{array}$ \\
\hline $\begin{array}{l}\text { Experimental } \\
\text { group n=30 }\end{array}$ & Pre-test & 5.96 & 2.73 & \multirow{2}{*}{$* 5.33$} \\
\cline { 2 - 4 } & Post-test & 15.2 & 3 & \multirow{2}{*}{} \\
\hline
\end{tabular}

The data presented in Table.4.3.1. Shows the mean post test scores of knowledge regarding Breast self examination. The 15.2 of the group were higher than mean pre test scores of knowledge regarding Breast self examination 5.96. The obtained standard deviation of knowledge regarding Breast self examination during post test was 3 and the pre test standard deviation was 2.73. The obtained't' value for the pre test and post test scores of knowledge regarding Breast self examination is $* 5.33$ when compared to table value which was significant at $\mathrm{p}<0.05$ it indicates that the knowledge level on women improved after video assisted teaching programme.

Association between Post-Test Scores of Knowledge Regarding Breast Self Examination with their Selected socio Demographic Variables.

Table.4.5: Association between post test scores of knowledge regarding breast self examination with selected demographic variables.

\begin{tabular}{|c|c|c|c|c|c|c|}
\hline Demographic variables & $\begin{array}{l}\text { Inadequate } \\
\text { knowledge }\end{array}$ & $\begin{array}{l}\text { Moderate } \\
\text { knowledge }\end{array}$ & $\begin{array}{l}\text { Adequate } \\
\text { knowledge }\end{array}$ & df & $\mathbf{X}^{2}$ & $\begin{array}{l}\text { Table } \\
\text { value }\end{array}$ \\
\hline \multicolumn{4}{|l|}{ Age in years. } & \multirow[t]{4}{*}{4} & \multirow[t]{4}{*}{3.564} & \multirow{4}{*}{$\begin{array}{l}0.468214 \\
\text { NS }\end{array}$} \\
\hline a)20-35 years & 0 & 3 & 2 & & & \\
\hline b) $35-45$ years & 0 & 3 & 14 & & & \\
\hline c) 45 years above & 0 & 2 & 6 & & & \\
\hline \multicolumn{4}{|l|}{ Religion. } & \multirow[t]{4}{*}{6} & \multirow[t]{4}{*}{0} & \multirow{4}{*}{$\begin{array}{l}1 \\
\text { NS }\end{array}$} \\
\hline a) Hindu & 0 & 8 & 22 & & & \\
\hline b) Muslim & 0 & 0 & 0 & & & \\
\hline c) Christian & 0 & 0 & 0 & & & \\
\hline \multicolumn{4}{|l|}{ Education status } & \multirow[t]{4}{*}{4} & \multirow[t]{4}{*}{4.174} & \multirow{4}{*}{$\begin{array}{l}0.382969 \\
\text { NS }\end{array}$} \\
\hline a) Illiterate & 0 & 2 & 2 & & & \\
\hline b) Primary education & 0 & 3 & 17 & & & \\
\hline c) Degree and above & 0 & 3 & 3 & & & \\
\hline \multicolumn{4}{|l|}{ Marital status. } & \multirow[t]{5}{*}{6} & \multirow[t]{5}{*}{4.189} & \multirow{5}{*}{$\begin{array}{l}0.651117 \\
\text { NS }\end{array}$} \\
\hline a) Unmarried & 0 & 5 & 5 & & & \\
\hline b) Married & 0 & 3 & 17 & & & \\
\hline c) Widow & 0 & 0 & 0 & & & \\
\hline d) Separated & 0 & 0 & 0 & & & \\
\hline
\end{tabular}


M. Porselvi et.al. Effectiveness of video assisted teaching on knowledge regarding breast self examination among women in selected rural area at Villupuram District.

\begin{tabular}{|c|c|c|c|c|c|c|}
\hline \multicolumn{7}{|c|}{ Table 4.5. Continued... } \\
\hline Occupation of the mother. & & & & \multirow[t]{5}{*}{6} & \multirow[t]{5}{*}{0.337} & \multirow{5}{*}{$\begin{array}{l}0.999297 \\
\text { NS }\end{array}$} \\
\hline a) House wife & 0 & 2 & 8 & & & \\
\hline b) Salaried & 0 & 0 & 0 & & & \\
\hline c) Business & 0 & 0 & 0 & & & \\
\hline d) Daily wages & 0 & 6 & 14 & & & \\
\hline Total number of pregnancy. & & & & \multirow[t]{5}{*}{6} & \multirow[t]{5}{*}{4.914} & \multirow{5}{*}{$\begin{array}{l}0.55489 \\
\text { NS }\end{array}$} \\
\hline a) Nil & 0 & 1 & 2 & & & \\
\hline b) $1-2$ & 0 & 1 & 14 & & & \\
\hline c) 3-4 & 0 & 5 & 5 & & & \\
\hline d) $5 \&$ above & 0 & 1 & 1 & & & \\
\hline Income of the family per month. & & & & \multirow[t]{5}{*}{6} & \multirow[t]{5}{*}{6.337} & \multirow{5}{*}{$\begin{array}{l}0.386517 \\
\text { NS }\end{array}$} \\
\hline a) Rs. $<5000$ & 0 & 1 & 2 & & & \\
\hline b)Rs. $5000-10000$ & 0 & 1 & 14 & & & \\
\hline c)Rs. $10000-15000$ & 0 & 5 & 5 & & & \\
\hline d)Rs. 15000 or above & 0 & 1 & 1 & & & \\
\hline Diet pattern. & & & & \multirow[t]{3}{*}{2} & \multirow[t]{3}{*}{0.596} & \multirow{3}{*}{$\begin{array}{l}0.742301 \\
\text { NS }\end{array}$} \\
\hline a) Vegetarian & 0 & 1 & 1 & & & \\
\hline b) Non vegetarian & 0 & 7 & 21 & & & \\
\hline $\begin{array}{l}\text { Is there any history of breast cancer in } \\
\text { family. }\end{array}$ & & & & \multirow[t]{3}{*}{2} & \multirow[t]{3}{*}{0.543} & \multirow[t]{3}{*}{$\begin{array}{l}0.762235 \\
\text { NS }\end{array}$} \\
\hline a) Yes & 0 & 2 & 3 & & & \\
\hline b) No & 0 & 6 & 19 & & & \\
\hline $\begin{array}{l}\text { Source of information regarding breast } \\
\text { cancer. }\end{array}$ & & & & \multirow[t]{5}{*}{6} & \multirow[t]{5}{*}{0.997} & \multirow[t]{5}{*}{$\begin{array}{l}0.985726 \\
\text { NS }\end{array}$} \\
\hline a) Teacher & 0 & 0 & 0 & & & \\
\hline b) Mass media & 0 & 2 & 8 & & & \\
\hline c)Health care providers & 0 & 5 & 13 & & & \\
\hline d) Other & 0 & 1 & 1 & & & \\
\hline
\end{tabular}

From the above table it is evident that there is no significant association exist between post test score of knowledge regarding Breast self examination with selected demographic variables.

\section{DISCUSSION}

Frequency and percentage distribution of women at selected village.

Among 30 samples according to age of the women $5(16.5 \%)$ belongs to $20-30$ years $17(5.7 \%)$ belongs to $35-45$ years and $8(26.5 \%)$ belongs to 45 years above according to religion $30(100 \%)$ wear. Hindu none of them in Christian Muslim and others according to educational qualification $4(13 \%)$ belongs to literate 20 $(66.6 \%)$ belongs to primary education 6 $(20.4 \%)$ belongs to degree and above and none of team in post graduate according to marital status $10(33.4 \%)$ belongs to unmarried $20(66.6 \%)$ belongs to married none of them in widow and separated according to occupation of mother 10 (33.4\%) belongs to house wife 20(66.6\%) belongs to daily wages none of them salaried and business according to total number of pregnancy $15(50 \%)$ belongs to $1-2,12(40 \%)$ belongs to $3-43 \quad(10 \%)$ belongs to 58 above according to income 3 (10.6\%) belongs to <Rs.500015 (50\%) belongs to Rs.5000-1000010 (33.4\%) belongs to $10000-150002(6 \%)$ belongs to vegetarian 28(94\%) belongs to non vegetarian according to breast cancer in family $5(16.5 \%)$ present of cancer $25(83.5 \%)$ absent of cancer according to source of information regarding breast cancer $10(33.4 \%)$ wear from mass media $18(60.6 \%)$ are from health care providers $2(6 \%)$ from other.

THE FIRST OBJECTIVES OF THE STUDY TO ASSESS THE PRE TEST AND POST TEST LEVEL OF KNOWLEDGE REGARDING BREAST SELF EXAMINATION AMONG WOMEN

The findings shows the pre test level of knowledge majority of women 25 $(83.4 \%)$ had inadequate knowledge and $5(16.6 \%)$ had moderately adequate knowledge. Post test level of knowledge majority of women $22(73 \%)$ had adequate knowledge $8(26.6 \%)$ had moderately adequate knowledge and none of them had inadequate knowledge.

THE SECOND OBJECTIVES OF THE STUDY IS TO ASSESS THE 


\section{EFFECTIVEESS OF VIDEO ASSISTED TEACHING ON KNOWLEDGE REGARDING BREAST SELF EXAMINATION AMONG WOMEN}

The finding of the study shows that pre test mean was 5.96 with the standard deviation of 2.73 and post test mean was 15.2 with the standard deviation of 3 the mean difference of pre test and post test is 9.23 standard error 1.73 .

The $T$ value is 5.33 is highly significant at $\mathrm{P}<0.05$ it indicates that the knowledge level of women are improved after video assisted teaching regarding breast self examination.

THE THIRD OBJECTIVE OF STUDY IS TO FIND ASSOCIATION BETWEEN POST LEVEL OF KNOWLEDGE REGARDING BREAST SELF EXAMINATION AMONG WOMEN WITH THEIR SELECTED DEMOGRAPHIC VARIABLES.

The find of study shows that there is no significant association between level of knowledge with previous knowledge regarding breast self examination and source of information at $\mathrm{P}>0.05$.

\section{CONCLUSION}

The finding of the study shows that in level of knowledge .pre-test mean was 5.96 with the standard deviation of 2.73 and post-test mean was 15.2 with the standard deviation of 3. The knowledge ' $\mathrm{T}$ ' value is 5.33 is highly significant at $\mathrm{P}<0.05$ the study concluded that video assisted teaching regarding breast self examination was effective and improved knowledge among women.

Acknowledgement: None

Conflict of Interest: None

Source of Funding: None

Ethical Approval: Approved

\section{REFERENCES}

1. Brunner and suddarth "A text book of medical surgical nursing -II, 13th edition published by Jaypee brothers (p) Ltd.

2. V Raman " A text book of maternity nursing edition is (19th edition) published by wolters kluwer (p) Ltd, New Delhi.

3. Siegel RL, Miller KD, and Jemal A. Cancer Statistics, 2017. CA Cancer J Clin. 2017; 67: 7-30.

4. Drukteinis JS, Mooney BP, Flowers CI, et al. Beyond mammography: new frontiers in breast cancer screening. Am J Med. 2013; 126: 472-479.

5. Sonnenschein $\mathrm{C}$, and Soto AM. Carcinogenesis explained within the context of a theory of organisms. Progress in biophysics and molecular biology. 2016; 1122: 70-76.

6. Qian BZ, and Pollard JW. Macrophage diversity enhances tumor progression and metastasis. Cell. 2010; 141: 39-51.

7. Polyak K. Breast cancer: origins and evolution. J Clin Invest. 2007; 117: 31553163.

8. Baumann M, Krause $\mathrm{M}$, and Hill R. Exploring the role of cancer stem cells in radioresistance. Nat Rev Cancer. 2008; 8: 545-554.

9. Smalley M, Piggott L, and Clarkson R. Breast cancer stem cells: obstacles to therapy. Cancer Lett. 2013; 338: 57-62.

10. El Helou R, Pinna G, Cabaud O, et al. miR600 Acts as a Bimodal Switch that Regulates Breast Cancer Stem Cell Fate through WNT Signaling. Cell reports. 2017; 18: 2256-2268.

11. Kasper M, Jaks V, Fiaschi M, et al. Hedgehog signalling in breast cancer. Carcinogenesis. 2009; 30: 903-911.

12. Sgroi DC. Preinvasive breast cancer. Annu Rev Pathol. 2010; 5: 193-221.

13. Deng CX. BRCA1: cell cycle checkpoint, genetic instability, DNA damage response and cancer evolution. Nucleic Acids Res. 2006; 34: 1416-1426.

14. Dine J, and Deng CX. Mouse models of BRCA1 and their application to breast cancer research. Cancer Metastasis Rev. 2013; 32: 25-37.

15. Tan-Wong SM, French JD, Proudfoo NJ, et al. Dynamic interactions between the promoter and terminator regions of the mammalian BRCA1 gene. P Natl Acad Sci USA. 2008; 105: 5160-5165. 
16. Bane AL, Beck JC, Bleiweiss I, et al. BRCA2 mutation-associated breast cancers exhibit a distinguishing phenotype based on morphology and molecular profiles from tissue microarrays. Am J Surg Pathol. 2007; 31: 121-128.

17. Balmana J, Diez O, Rubio IT, et al. BRCA in breast cancer: ESMO Clinical

18. Chen S, and Parmigiani G. Meta-analysis of BRCA1 and BRCA2 penetrance. J Clin Oncol. 2007; 25: 1329-1333.

19. N, and Gnant M. Breast cancer. The Lancet. 2017; 389: 1134-1150.

20. Davis NM, Sokolosky M, Stadelman K, et al. Deregulation of the EGFR/PI3K/PTEN/Akt/mTORC1 pathway in breast cancer: possibilities for therapeutic intervention. Oncotarget. 2014; 5: 46034650.

21. Invasion. Frontiers in pharmacology. 2015; 6: 283

22. Ali R, and Wendt MK. The paradoxical functions of EGFR during breast cancer progression. Signal transduction and targeted therapy. 2017; 2: 16042.

23. Poole CJ, and van Riggelen J. MYC-Master Regulator of the Cancer Epigenome and Transcriptome. Genes. 2017; 8: 142.

24. Jung M, Russell AJ, Liu B, et al. A Myc Activity Signature Predicts Poor Clinical Outcomes in Myc-Associated Cancers. Cancer Res. 2017; 77: 971-981.

25. Fernandez-Medarde A, and Santos E. Ras in cancer and developmental diseases. Genes \& cancer. 2011; 2: 344-358.

26. Varna M, Bousquet $G$, Plassa LF, et al. TP53 status and response to treatment in breast cancers. J Biomed Biotechnol. 2011; 2011: 284584.

27. Hientz K, Mohr A, Bhakta-Guha D, et al. The role of p53 in cancer drug resistance and targeted chemotherapy. Oncotarget. 2017; 8: 8921-8946.

28. Lefebvre C, Bachelot T, Filleron T, et al. Mutational Profile of Metastatic Breast Cancers: A Retrospective Analysis. PLoS medicine. 2016; 13: e1002201.

29. Desmedt C, Zoppoli G, Gundem G, et al. Genomic Characterization of Primary Invasive Lobular Breast Cancer. J Clin Oncol. 2016; 34: 1872-1881.

30. Dabiri S, Moeini Aghtaei M, Shahryari J, et al. Maspin Gene Expression in Invasive Ductal Carcinoma of Breast. Iranian journal of pathology. 2016; 11: 104-111.
31. Washbrook E. Risk factors and epidemiology of breast cancer. Women's Health Medicine. 2006; 3: 8-14.

32. Dall GV, and Britt KL. Estrogen Effects on the Mammary Gland in Early and Late Life and Breast Cancer Risk. Front Oncol. 2017; 7: 110 .

33. Horn J, Asvold BO, Opdahl S, et al. Reproductive factors and the risk of breast cancer in old age: a Norwegian cohort study. Breast Cancer Res Treat. 2013; 139: 237-243.

34. Beral V. Breast cancer and hormonereplacement therapy in the Million Women Study. Lancet. 2003; 362: 419-427.

35. Liu J-Y, Chen T-J, and Hwang S-J. The Risk of Breast Cancer in Women Using Menopausal Hormone Replacement Therapy in Taiwan. International journal of environmental research and public health. 2016; 13: 482.

36. Narod SA. Hormone replacement therapy and the risk of breast cancer. Nature reviews. Clinical oncology. 2011; 8: 669676.

37. Makarem N, Chandran U, Bandera EV, et al. Dietary fat in breast cancer survival. Annu Rev Nutr. 2013; 33: 319-348.

38. Knight JA, Fan J, Malone KE, et al. Alcohol consumption and cigarette smoking in combination: A predictor of contralateral breast cancer risk in the WECARE study. Int J Cancer. 2017; 141: 916-924.

39. Catsburg C, Miller AB, and Rohan TE. Active cigarette smoking and risk of breast cancer. Int J Cancer. 2015; 136: 2204-2209.

40. Kispert S, and McHowat J. Recent insights into cigarette smoking as a lifestyle risk factor for breast cancer. Breast Cancer : Targets and Therapy. 2017; 9: 127-132.

41. The benefits and harms of breast cancer screening: an independent review. Lancet. 2012; 380: 1778-1786.

42. van den Ende C, Oordt-Speets AM, Vroling $\mathrm{H}$, et al. Benefits and harms of breast cancer screening with mammography in women aged 40-49 years: A systematic review. Int J Cancer. 2017; 141: 1295-1306.

43. Greenwood HI, Heller SL, Kim S, et al. Ductal Carcinoma in Situ of the Breasts: Review of MR Imaging Features. Radiographics. 2013; 33: 1569-1588.

44. Morrow M, Waters J, and Morris E. MRI for breast cancer screening, diagnosis, and treatment. Lancet. 2011; 378: 1804-1811. 
M. Porselvi et.al. Effectiveness of video assisted teaching on knowledge regarding breast self examination among women in selected rural area at Villupuram District.

45. Enriquez L, and Listinsky J. Role of MRI in breast cancer management. Cleve Clin $\mathbf{J}$ Med. 2009; 76: 525-532.

46. Nagini S. Breast Cancer: Current Molecular Therapeutic Targets and New Players. Anticancer agents in medicinal chemistry. 2017; 17: $152-163$.
How to cite this article: M. Porselvi, M. Muthamizh, E. Pathima et.al. Effectiveness of video assisted teaching on knowledge regarding breast self examination among women in selected rural area at Villupuram District. Gal Int J Health Sci Res. 2021; 6(3): 75-81. DOI: https://doi.org/10.52403/gijhsr.20210712 